\title{
In vitro studies on optimal requirements for the growth of Spironucleus vortens, an intestinal parasite of the freshwater angelfish
}

\author{
Somboon Sangmaneedet, Stephen A. Smith* \\ Department of Biomedical Sciences and Pathobiology, Virginia-Maryland Regional College of Veterinary Medicine, \\ Virginia Polytechnic Institute and State University, Blacksburg, Virginia 24061, USA
}

\begin{abstract}
Spironucleus vortens were cultivated in either an artificial medium at different temperatures, or in medium at various $\mathrm{pH}$ conditions or supplemented with different bile concentrations at $25^{\circ} \mathrm{C}$. Temperature, $\mathrm{pH}$ and bile requirements for the optimal growth of the parasite were determined. Parasites multiplied quickly at 28 and $31^{\circ} \mathrm{C}$ and reached maximum numbers on Day 4 of cultivation, whereafter they did not survive. At $25^{\circ} \mathrm{C}$, parasites survived longer than those at 28 and $31^{\circ} \mathrm{C}$ with no difference in multiplication rate during the exponential phase. The longest survival period was seen at $22^{\circ} \mathrm{C}$, although the growth rate of the parasite was not as high as those at $25^{\circ} \mathrm{C}$. At a higher temperature of $37^{\circ} \mathrm{C}$, no parasites were observed alive after the second day of cultivation. Optimal pH range for the parasite's growth was 6.5 to 7.5 , with the highest cell number at $\mathrm{pH} 7.5$. Parasites survived longest (15 d) at $\mathrm{pH} 6.0$, although the maximum number of cells was lower than those at the optimal pH. Parasites were dead within $24 \mathrm{~h}$ at $\mathrm{pH}$ levels above 8.5 or below 5.5. All cultures supplemented with either bovine or fish bile yielded numbers of parasites lower than cultures with no bile. In addition, parasite growth was significantly suppressed in medium supplemented with higher concentrations of bile These results indicate that the optimal condition for the in vitro cultivation of $S$. vortens is $25^{\circ} \mathrm{C}$ and $\mathrm{pH}$ 6.5 to 7.5 without supplementation with bile.
\end{abstract}

KEY WORDS: Hexamitid - Diplomonad S Spironucleus vortens - Angelfish P Pterophyllum scalare In vitro $\cdot$ Cultivation $\cdot$ Protozoa

\section{INTRODUCTION}

Spironucleus spp. are parasitic flagellates found in both freshwater and saltwater fish. They have been recorded in marine gadoids, Atlantic cod and haddock (Poynton \& Morrison 1990), and Atlantic salmon (Sterud et al. 1997). In freshwater fish, Spironucleus spp. have been recorded in grayling (Sterud et al. 1997), burbot (Sterud 1998a), and cichlids, including angelfish (Kulda \& Lom 1964b, Specht et al. 1989, O'Brien et al. 1993, Poynton et al. 1995), and cyprinids (Molnár 1974). The parasite has been associated either locally in the digestive tract or systemically in various organs of the fish. They can cause an enteritis, especially of the posterior intestine, varying in severity from a diffuse lymphoplasmacytic infiltration to a severe

·Corresponding author: E-mail: stsmith7@vt.edu intestinal necrosis (O'Brien et al. 1993). Spironucleus spp. may reach the blood stream and liver by invasion across the injured intestinal wall, and are capable of causing severe parasitemia in a host under stress conditions (Molnár 1974). It has been suggested that Spironucleus spp. cause systemic infection because they can invade intestinal mucosa and disseminate to other tissues (Siddall et al. 1992). In sea-caged Atlantic salmon Salmo salar L., Spironucleus barkhanus has been reported causing the death of fish, and the parasites were found in large numbers in most internal organs (Mo et al. 1990, Poppe et al. 1992).

Spironucleus vortens Poynton et al., 1995 was first successfully isolated from the freshwater angelfish Pterophyllum scalare. The organism can be maintained and propagated in artificial medium (Poynton et al. 1995). A few studies have suggested the in vitro growth requirements of fish hexamitids (Poynton et al. 
1995, Sterud 1998b), but none have examined the specific optimal requirements for growth of $S$. vortens Although $S$. barkhanus cultivated in bile-supplemented medium have shown a slight difference in optimal temperatures between strains isolated from salmon and grayling (Sterud 1998b), the optimal pH and bile requirement for Spironucleus spp. are still unknown. In addition, most of the in vitro cultivation of diplomonads, including fish hexamitids, have been done in culture medium supplemented with bovine bile (Keister 1983, Buchmann \& Uldal 1996, Sterud 1998b). To date, none of the fish hexamitids have been cultivated in medium supplemented with fish bile. In the present study, bile originating from cattle or fish was added to the culture medium and evaluated with temperature and $\mathrm{pH}$ for the optimal conditions maximizing the in vitro growth of $S$. vortens.

\section{MATERIALS AND METHODS}

Parasite cultivation. Cryopreserved Spironucleus vortens were obtained from the American Type Culture Collection (ATCC No. 50386, Manassas, VA, USA). The parasites were thawed by immersion of the vial into water at $35^{\circ} \mathrm{C}$ for $2 \mathrm{~min}$ and the suspension $(0.5 \mathrm{ml})$ immediately added to a $16 \times 125 \mathrm{~mm}$ sterile screw-capped glass tube containing $13 \mathrm{ml}$ culture medium. The culture tube was tightly closed and placed on a $15^{\circ}$ horizontal slant in an incubator without light at $25^{\circ} \mathrm{C}$. The parasites were propagated and subcultivated every $6 \mathrm{~d}$ by transferring $0.1 \mathrm{ml}$ of parasite suspension to a sterile tube with $13 \mathrm{ml}$ fresh culture medium.

Culture medium. The flagellates were cultivated in sterile TYI-S-33 medium (ATCC No. 350-X) at pH 6.8 supplemented with the antibiotics, penicillin (2000 U $\mathrm{ml}^{-1}$ ) and gentamicin (50 $\mu \mathrm{g} \mathrm{ml}^{-1}$ ).

Parasite cell counting. The concentration (average cell number $\mathrm{ml}^{-1}$ ) of Spironucleus vortens in culture medium was determined daily by automatic cell counter (CASY ${ }^{\otimes}$; model TTC, Schärfe System GmbH, Germany). The parasite suspension was gently mixed and aliquots of 5 or $10 \mu l$ were added into counter containers with $10 \mathrm{ml}$ PBS, pH 7.4.

Determination of optimal temperature. Culture medium ( $2 \mathrm{ml}, \mathrm{pH}$ 6.8) with Spironucleus vortens concentration of 5000 cells ml $\mathrm{m}^{-1}$ was established in $4 \mathrm{ml}$ screw-capped glass tubes. The parasites were incubated and allowed to grow in thermostat-regulated incubators without light at $22,25,28,31,34$ and $37^{\circ} \mathrm{C}$. The cell cultures at each temperature were performed in triplicate. Concentrations of $S$. vortens were determined every $24 \mathrm{~h}$ until no parasites were observed alive.
Determination of optimal pH. Parasite cultures

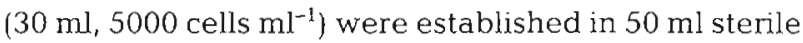
tissue culture flasks. The $\mathrm{pH}$ of cultures was adjusted gradually from the original $\mathrm{pH}(6.8)$ to the appropriate final incubation $\mathrm{pH}: 4.0,4.5,5.0,5.5,6.0,6.5,7.0,7.5$, $8.0,8.5,9.0,9.5$ or 10.0 within $4 \mathrm{~d}$ of culture initiation. The $\mathrm{pH}$ of cultures were measured daily by a $\mathrm{pH}$ meter (Accumet ${ }^{\circledR} \mathrm{pH}$ meter 10, Fisher Scientific, Pittsburgh, PA) and were adjusted to the final incubation $\mathrm{pH}$ by sterile $0.1 \mathrm{~N} \mathrm{NaOH}$ or $0.1 \mathrm{~N} \mathrm{HCl}$. The larger volume of culture media used in this experiment allowed for the aseptic removal of a small sample of media for $\mathrm{pH}$ determination, thus preventing the contamination of the primary experimental culture with a non-sterile $\mathrm{pH}$ probe. The culture flasks were tightly capped and incubated without light at $25^{\circ} \mathrm{C}$. The average cell numbers of 3 aseptically removed subsamples were determined daily by the automatic cell counter as previously described.

Determination of bile requirement. Parasite cultures $\left(2 \mathrm{ml}, 5000\right.$ cells $\left.\mathrm{ml}^{-1}\right)$ with different concentrations $(0.00,0.05,0.20,0.40,0.80,1.60,3.20$ and $6.40 \mathrm{mg}$ $\mathrm{ml}^{-1}$ ) of bovine bile (Sigma Chemical Co., No. B-8381) were established in $4 \mathrm{ml}$ screw-capped glass tubes. Parasite cultures at each bile concentration were performed in triplicate and allowed to grow at $25^{\circ} \mathrm{C}$. Concentrations of Spironucleus vortens were determined every $24 \mathrm{~h}$ until no parasites were observed alive. In addition to bovine bile, fish bile collected directly from the gall bladder of hybrid Oreochromis aureus was pooled and used as a supplement in the culture medium. Parasite cultures were established containing fish bile concentrations of 0 (control), 1.0, 2.0, 4.0, 6.0 $8.0,10.0$ and $12.5 \%$. Procedures for evaluating the parasite's fish bile requirement were done in the same manner as described for the bovine bile investigation.

Criteria for determining optimal condition. Optimal conditions for the growth of the parasites were based on a combination of factors which included average cell number $\mathrm{ml}^{-1}$, growth rate, survival time, and cell conditions (motility and morphology). The motility and shape of the parasites were observed under a compound microscope. Initially, the optimal temperature for growth of the organism was evaluated using previously reported culture conditions (Poynton et al. 1995), then the optimal $\mathrm{pH}$ and concentration of bile were determined based on this optimal temperature. Any condition of temperature, $\mathrm{pH}$ and bile that yielded high numbers of active motile flagellates with a long survival period was considered an optimal condition.

Statistical analysis. Growth rates of Spironucleus vortens during the exponential phase were analyzed and compared by a SAS statistical program (SAS Institute Inc., Cary, NC). Numbers of parasites during the exponential phase were transformed to a ln-growth 


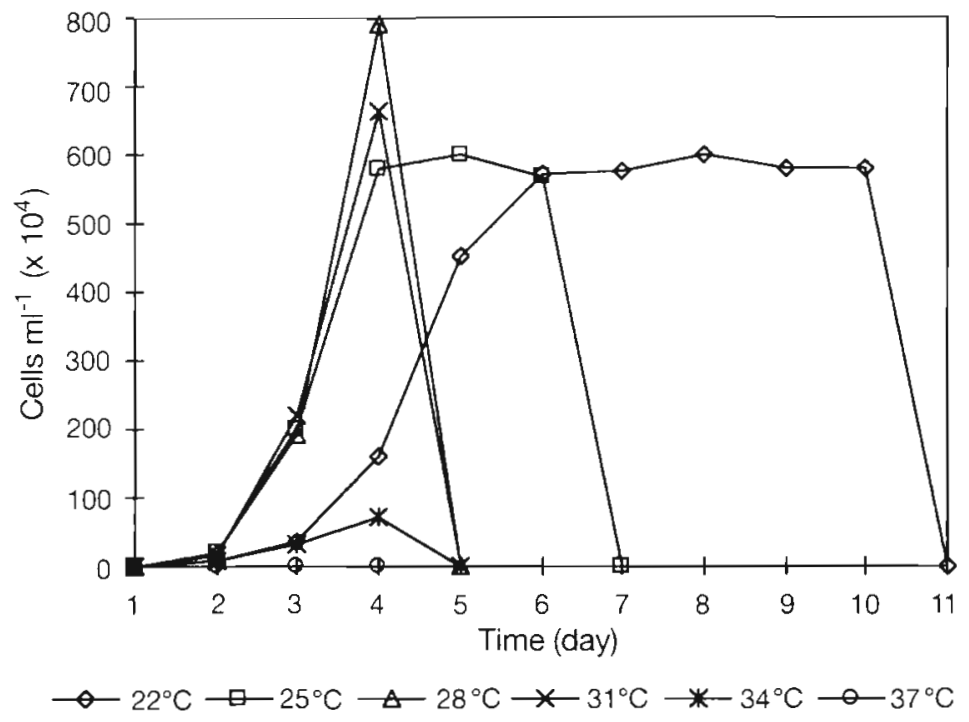

Fig. 1. Spironucleus vortens. Growth of the parasite cultivated at different temperatures $\left({ }^{\circ} \mathrm{C}\right)$ cultures are shown in Fig. 2. An equation representing the growth of each curve is $\ln$ (cell no. $)=\beta_{0}+\beta_{1}$ day. The growth rates $\left(\beta_{1}\right)$ at 22 , $25,28,31$, and $34^{\circ} \mathrm{C}$ during Days 2 to 4 were $1.52,1.71,1.84,1.86$, and 1.02 , respectively. The parasites multiplied faster at $22,25,28$ and $31^{\circ} \mathrm{C}$ than those at $34^{\circ} \mathrm{C}$. There was no significant difference between the proportional increase in cell numbers of cultures at $22,25,28$ and $31^{\circ} \mathrm{C}$. Although the parasites multiplied at $22^{\circ} \mathrm{C}$ with no difference in growth rate from those at 25,28 , and $31^{\circ} \mathrm{C}$, the number of parasites at $22^{\circ} \mathrm{C}$ during Days 2 to 4 was significantly lower (Table 1 ). The parasites cultured at 22 and $34^{\circ} \mathrm{C}$ had similar cell numbers on the second and third day of cultivation; however, by Day 4 the number of parasites at $22^{\circ} \mathrm{C}$ was significantly higher than those at $34^{\circ} \mathrm{C}$. curve in order to stabilize the variances for analysis purposes. The exponential increases (slope) of growth and the number of parasites during the exponential phase were analyzed and compared by Tukey's HSD at $\alpha=0.05$.

\section{RESULTS}

\section{Optimal temperature}

Growth of Spironucleus vortens cultivated under different temperatures is shown in Fig. 1. No parasites were observed alive in the culture at $37^{\circ} \mathrm{C}$ after $24 \mathrm{~h}$ of culture initiation. At 28, 31 and $34^{\circ} \mathrm{C}$, parasites were observed alive for only the first $4 \mathrm{~d}$ of cultivation. The cultured cells, except those at 34 and $37^{\circ} \mathrm{C}$, started multiplying with a lag phase followed by an exponential phase. The lag phases and the exponential phases of cultures at 25,28 and $31^{\circ} \mathrm{C}$ were $1 \mathrm{~d}$ shorter than those at $22^{\circ} \mathrm{C}$. The cultures at 22,25 , 28 and $31^{\circ} \mathrm{C}$ yielded maximum cell numbers of $6.0,6.0,7.91$ and 6.7 million cells $\mathrm{ml}^{-1}$, respectively. The cultured cells at $25^{\circ} \mathrm{C}$ reached maximum cell numbers within $5 \mathrm{~d}$, while those at $22^{\circ} \mathrm{C}$ reached the same cell number within $8 \mathrm{~d}$. However, cells in the cultures at $22^{\circ} \mathrm{C}$ were observed alive up to $10 \mathrm{~d}$ of the cultivation.

The ln-transformed growth curves of Spironucleus vortens during Days 2 to 4 of
Table 1. Spironucleus vortens. Average number of parasites $\left(\times 10^{4} \mathrm{cells} \mathrm{m}^{-1}\right)$ from Days 2 to 4 of culture at different temperatures. Back-transformed means within a row (day) followed by different letters are significantly different at $\alpha=0.05$ according to Tukey's HSD

\begin{tabular}{|lrrrrr|}
\hline \multirow{2}{*}{ Day } & \multicolumn{5}{c|}{ Temperature $\left({ }^{\circ} \mathrm{C}\right)$} \\
& 22 & 25 & 28 & \multicolumn{1}{c|}{31} & \multicolumn{1}{c|}{34} \\
\hline 2 & $7.18^{\mathrm{a}}$ & $18.84^{\mathrm{b}}$ & $20.04^{\mathrm{b}}$ & $16.05^{\mathrm{b}}$ & $9.38^{\mathrm{a}}$ \\
3 & $34.52^{\mathrm{a}}$ & $198.68^{\mathrm{b}}$ & $192.92^{\mathrm{b}}$ & $212.72^{\mathrm{b}}$ & $31.77^{\mathrm{a}}$ \\
4 & $149.73^{\mathrm{a}}$ & $580.03^{\mathrm{b}}$ & $790.95^{\mathrm{b}}$ & $663.91^{\mathrm{b}}$ & $71.83^{\mathrm{c}}$ \\
\hline
\end{tabular}

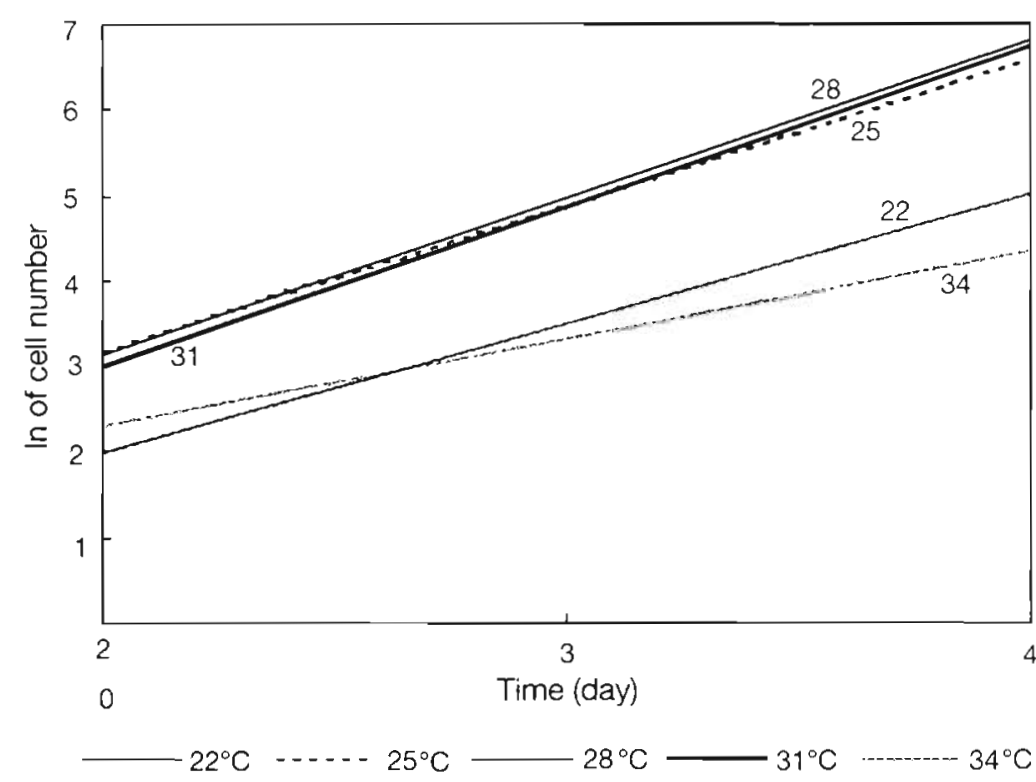

Fig. 2. Spironucleus vortens. Transformed growth curves of the parasite cultivated at different temperatures $\left({ }^{\circ} \mathrm{C}\right)$ 


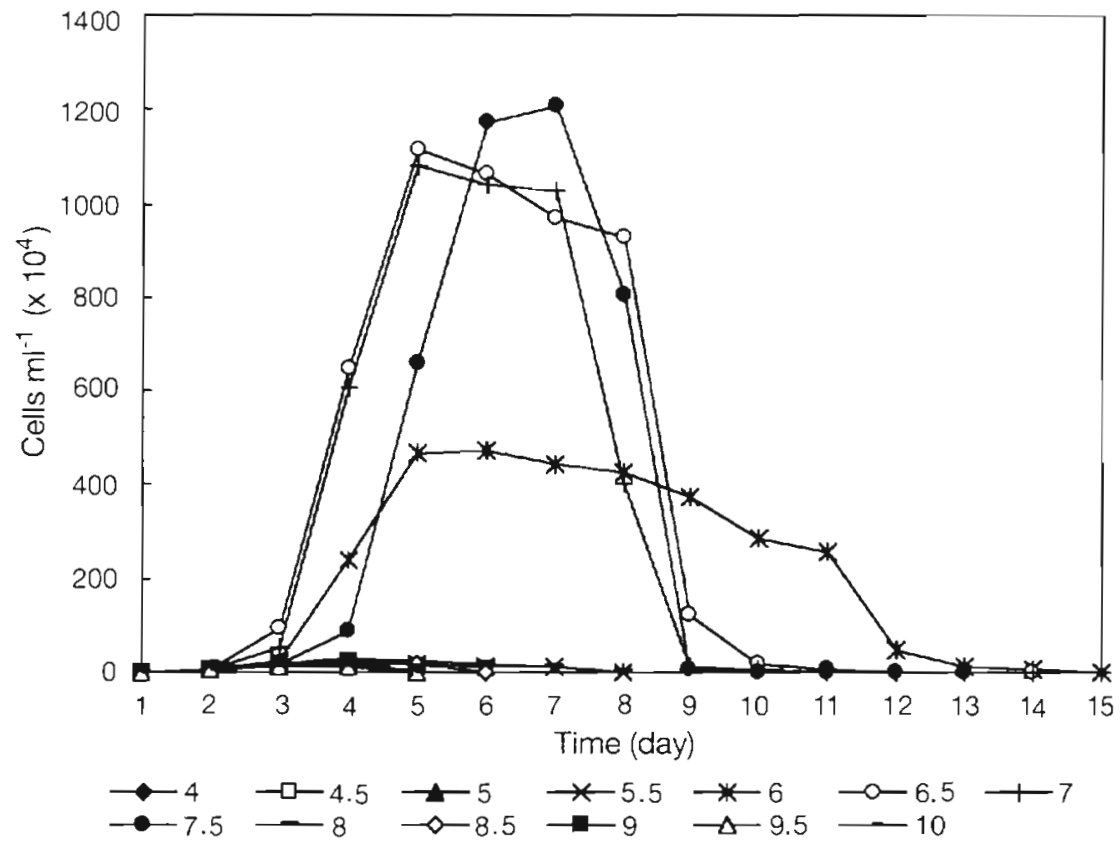

Fig. 3. Spironucleus vortens. Growth of the parasite cultivated under different pH conditions

Under microscopic observation, Spironucleus vortens cultivated at temperature ranges from 22 to $31^{\circ} \mathrm{C}$ were not different in shape. The majority of cell populations were pyriform in shape with a lower percentage of multinucleated trophozoites. A high percentage (12 to $17 \%$ ) of abnormal trophozoites was seen in the culture at $34^{\circ} \mathrm{C}$. The parasites at each temperature actively moved forward in the culture medium, and were less active only the last few days of cultivation.

\section{Optimal pH}

Growth of Spironucleus vortens cultivated under different $\mathrm{pH}$ conditions is shown in Fig. 3. Parasites had no difference in growth rates during the first $2 \mathrm{~d}$ of cultivation. The fastest growth rates were observed between $\mathrm{pH} 6.5$ and 7.5 . The parasites cultivated at $\mathrm{pH} 6.5$ and 7.0 were similar in growth patterns during the first $6 \mathrm{~d}$ of cultivation, and they had a $1 \mathrm{~d}$ shorter period of multiplication compared to those incubated at $\mathrm{pH}$ 7.5. However, the highest average cell number $\left(1.21 \times 10^{7}\right.$ cells $\left.\mathrm{ml}^{-1}\right)$ was observed in culture at $\mathrm{pH}$ 7.5. The lowest $\mathrm{pH}$ at which the organisms had a moderate growth rate and a long survival period was 6.0. Parasites survived only a few days at pH 5.5, 8.0 and 8.5 and were killed within $24 \mathrm{~h}$ at a pH above 8.5 or below 5.5 .

\section{Bile requirements}

Spironucleus vortens in medium (pH 6.8) supplemented with bovine bile concentrations lower than $3.2 \mathrm{mg} \mathrm{ml}^{-1}$ multiplied slowly during the first $3 \mathrm{~d}$ of cultivation. Parasites multiplied gradually with the highest growth rate during Days 4 to 5 . The cultured cells in the medium supplemented with bile concentrations lower than $1.6 \mathrm{mg}$ $\mathrm{ml}^{-1}$ had similar replication rates after Day 5 of cultivation. All cultures supplemented with bovine bile had maximum numbers of cells lower than the control culture with no bile (Fig. 4). Cell growth was suppressed at high concentrations ( 3.2 and $6.4 \mathrm{mg} \mathrm{ml}^{-1}$ ) of bovine bile. The numbers of cells at these higher concentrations of bile gradually decreased from the first day of cultivation until no cells were observed alive after Day 5 .

The parasites were also suppressed in medium supplemented with fish bile (Fig. 5). The average numbers of parasites $\mathrm{ml}^{-1}$ at all concentrations of fish bile were lower than those in the control culture with no bile. Parasites cultivated in fish bile-supplemented (1 to $8 \%$ ) medium multiplied slowly during the lag phase,

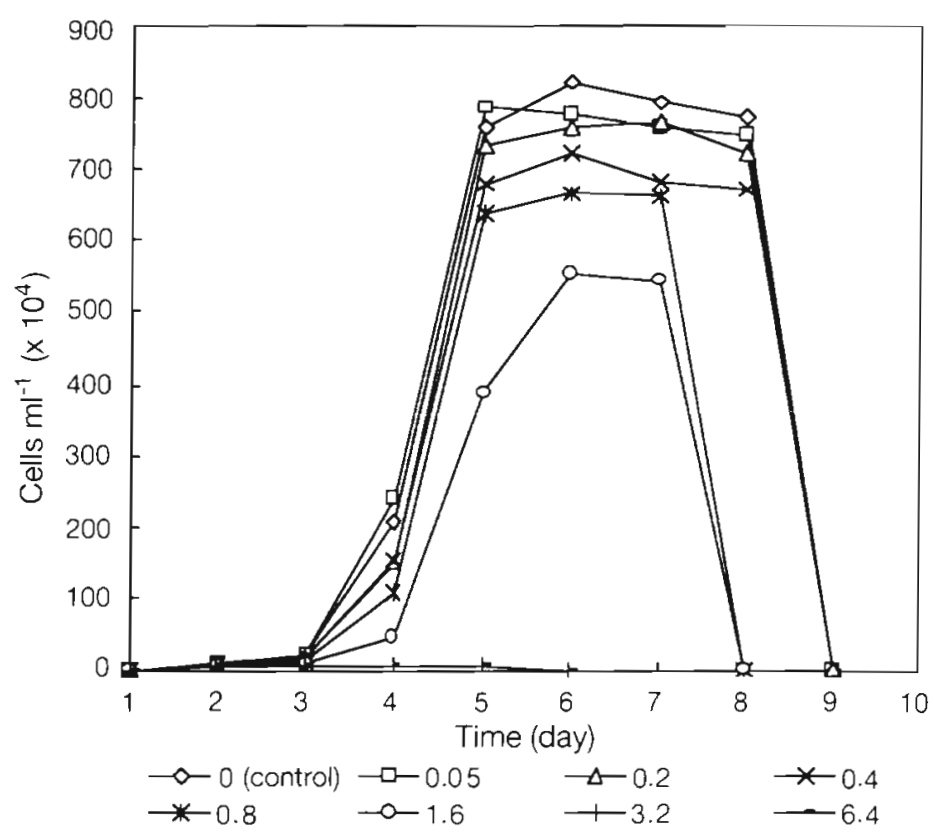

Fig. 4. Spironucleus vortens. Growth of the parasite cultivated in

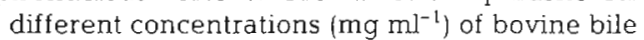




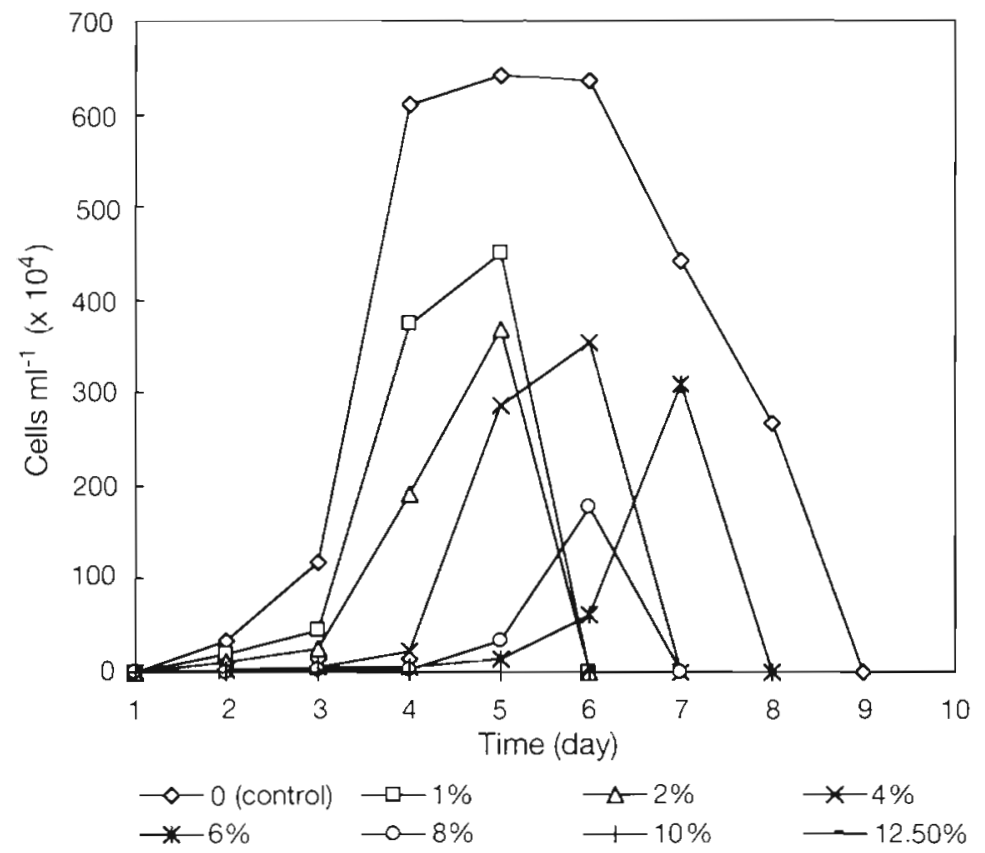

Fig. 5. Spironucleus vortens. Growth of the parasite cultivated in different concentrations (\%) of fish bile

and no cells were observed alive after they reached peak numbers. In cultures supplemented with $10 \%$ fish bile, the highest number of parasites was $6.3 \times 10^{3}$ cells $\mathrm{ml}^{-1}$, and only 200 cells $\mathrm{ml}^{-1}$ of parasites were observed alive on the last day of cultivation. At $12.5 \%$ fish bile supplementation, the number of parasites in cultures gradually decreased and no cells were observed alive on Day 4 of cultivation.

\section{DISCUSSION}

Spironucleus vortens are highly motile flagellates. They actively move forward in the culture medium at temperatures ranging from 22 to $34^{\circ} \mathrm{C}$. Although $S$. vortens has been reported to grow and reproduce between 25 and $31^{\circ} \mathrm{C}$ in culture medium (Poynton et al. 1995), the present study suggests that the range of temperatures is broader, extending from a low of $22^{\circ} \mathrm{C}$ to a high of $34^{\circ} \mathrm{C}$. At $22^{\circ} \mathrm{C}$ the parasites are less active via microscopic observation than those at the higher temperatures, but survive longer. This suggests that the long-term risk of maintaining a $S$. vortens infection in angelfish may be increased when the environmental temperature is decreased to $22^{\circ} \mathrm{C}$.

In the artificial medium, normal pyriform-shaped trophozoites were the dominant form seen throughout the cultivation period at all temperatures, and they have been reported to be the typical form of the free flagellate found in the intestinal lumen of angelfish
(Poynton et al. 1995). The dividing trophozoites which resembled bifurcated poles (Vshaped cells) were found in the highest number on the second day of cultivation. The dividing trophozoites did not always move forward in one direction, but sometimes in an opposite direction. Irregular (abnormal) multinucleated trophozoites were also found in low numbers throughout the cultivation period, with a higher percentage (12 to $17 \%$ ) in the culture at $34^{\circ} \mathrm{C}$, suggesting that high temperature $\left(34^{\circ} \mathrm{C}\right)$ is a factor inducing failure of cytokinesis of the parasite resulting in a decrease in the number of new free-flagellated trophozoites. Cysts were not observed in any of the cultures. To date, cysts of fish hexamitids are very rare either in cell culture or in host feces. They were reported in one early study of Octomitus salmonis in trout (Moore 1922), but were not detected in recent studies (Kulda \& Lom 1964a, Kent et al. 1992, Tojo \& Santamarina 1998). Therefore, it is probable that trophozoites, not cysts, of fish hexamitids play an important role in transmission in a natural condition

The optimal temperature for Spironucleus vortens in vitro growth in this study was determined to be $25^{\circ} \mathrm{C}$ because the parasites had a high replication rate, good motility, and extended survival period of up to $6 \mathrm{~d}$. Although at $22^{\circ} \mathrm{C}$ the organisms survived longest and had no difference in growth rate compared to those at $25^{\circ} \mathrm{C}$, they were less active throughout the culture period and required a longer period to reach a maximum number. At 28 and $31^{\circ} \mathrm{C}$, the parasites had a high replication rate, reached maximum numbers by Day 4 , but did not survive after that time. Either a shortage of nutrients and/or increased waste products released from live or dead cells are factors that may have contributed to the death of the parasites. In addition, temperature was considered to be the primary factor in the death of $S$. vortens in cultures maintained at $34^{\circ} \mathrm{C}$ or higher. The parasite's growth was significantly suppressed and was lethal within 24 h at $37^{\circ} \mathrm{C}$.

Fish are poikilothermic animals which adapt to changes in water temperature. Freshwater angelfish Pterophyllum scalare are indigenous in a tropical zone, South America: Amazon River (Axelrod 1985), and have been successfully bred and maintained in captivity under warmwater conditions. The most suitable temperature for raising angelfish ranges from 22 to $30^{\circ} \mathrm{C}$ (Mills et al. 1988). Therefore, the present study indicates that an appropriate temperature for raising angelfish is also suitable for facilitating the growth of Spironucleus vortens. It has been suggested that high temperatures (above $28^{\circ} \mathrm{C}$ ) can sometimes help in 
controlling hexamitid infections (Bassleer 1983). The present study supports this suggestion in that the trophozoites of $S$ vortens are suppressed and rapidly killed at high temperature. Thus, maintaining higher water temperatures may help decrease the number of trophozoites in the host and might minimize the rate of infection.

There have been few studies reporting the optimal conditions for fish hexamitids. The optimal temperature and $\mathrm{pH}$ for Hexamita salmonis isolated from rainbow trout were $10^{\circ} \mathrm{C}$ and $\mathrm{pH} 7.5$ to 8.0 (Buchmann \& Uldal 1996). Spironucleus barkhanus isolated from grayling and salmon have a suitable temperature range for growth from 5 to $20^{\circ} \mathrm{C}$ (Sterud 1998b). Both of these organisms are parasites of coldwater fish. In the present study, the suitable temperature range for $S$. vortens is 22 to $25^{\circ} \mathrm{C}$, which is higher than the previously mentioned species. However, optimal pH $(6.5$ to 7.5 ) for the growth of $S$. vortens is close to that reported for $H$. salmonis. Thus, it is obvious that different species of hexamitids have different optimal conditions for growth due to the adaptation of the hosts to environmental conditions

Bile concentrations between 0.03 and $0.96 \mathrm{mg} \mathrm{ml}^{-1}$ have been reported to stimulate growth of Hexamita salmonis cultivated in artificial medium (Buchmann \& Uldal 1996). However, the present study demonstrated that bile was not a requirement for the growth of Spironucleus vortens. In addition, the growth of the parasite was significantly suppressed at higher concentrations of either bovine (3.2 and $6.4 \mathrm{mg} \mathrm{ml}^{-1}$ ) or fish (10 and $12.5 \%$ ) bile. Spironucleus sp. have been reported frequently to cause diseases in many aquarium fishes (Molnár 1974) including the freshwater angelfish (O'Brien et al. 1993). The parasites are normally found in the intestine (O'Brien et al. 1993, Poynton et al. 1995), but may be found in other organs including the gall bladder (Molnár 1974, Sterud 1998b). However, the results of this study indicate that $S$. vortens is less tolerant to bile, therefore suggesting that it may only accidentally enter the gall bladder during heavy intestinal or systemic infections.

The in vitro environmental conditions such as temperature, $\mathrm{pH}$ and concentration of bile are all important factors in maximizing or suppressing the growth of the parasite. In this study, a temperature of $25^{\circ} \mathrm{C}$ and $\mathrm{pH}$ between 6.5 and 7.5 were considered as the optimal conditions for the parasite growth. However, Spironucleus vortens cultivated in culture medium at $25^{\circ} \mathrm{C}$ during routine cultivation $(13 \mathrm{ml})$ and in the $\mathrm{pH}$ experiment $(30 \mathrm{ml})$ survived longer than those cultivated in the temperature experiment $(2 \mathrm{ml})$. Thus, the amount of nutrient (medium) provided to the organisms may also be considered an important factor in the growth and survival requirements.
Spironucleus vortens has been found mostly in the middle to posterior region of angelfish's intestine (Poynton et al. 1995). The present study is useful in explaining the microhabitat of $S$. vortens. The anterior intestine, which presumably contains a higher concentration of bile, is not suitable for long-term parasite survival and the number of parasites should be lower in this region. Conversely, the number of parasites should be higher in the middle and posterior intestine due to the lower concentration of bile in these areas.

Acknowledgements. We wish to thank Dr Sarah L. Poynton for helpful suggestions in this research, and to Daniel Ward for help with the statistical analysis.

\section{LITERATURE CITED}

Axelrod HR (1985) The angelfishes, Pterophyllum. Trop Fish Hobbyist 5:34-53

Bassleer G (1983) Disease prevention and control. Freshw Mar Aquar 6:38-41, 58-60

Buchmann $\mathrm{K}$, Uldal A (1996) Temperature, $\mathrm{pH}$ and bile dependent in vitro cultivation of Hexamita salmonis from rainbow trout Oncorhynchus mykiss intestine. Dis Aquat Org 24:169-172

Keister DB (1983) Axenic culture of Giardia lamblia in TYI-S33 medium supplemented with bile. Trans R Soc Trop Med Hyg 77:487-488

Kent ML, Ellis J, Fournie JW, Dawe SC, Bagshaw JW, Whitaker DJ (1992) Systemic hexamitid (Protozoa: Diplomonadida) infection in seawater pen-reared chinook salmon Oncorhynchus tshawytscha. Dis Aquat Org 14 $81-89$

Kulda J, Lom J (1964a) Remarks on the diplomastigine flagellates from the intestine of fishes. Parasitology 54:753-762

Kulda J, Lom J (1964b) Spironucleus elegans Lavier, parasite of fish. Cesk Parasitol 11:187-192

Mills D, Sands D, Scott PW (1988) The concise encyclopedia of tropical aquarium fishes. Crescent Books, New York, p $130-146$

Mo TA, Poppe TT, Iversen L (1990) Systemic hexamitosis in salt-water reared Atlantic salmon (Salmo salar L.). Bull Eur Assoc Fish Pathol 10:69-70

Molnár K (1974) Data on the 'octomitosis' (spironucleosis) of cyprinids and aquary fishes. Acta Vet Acad Sci Hung 24: 99-106

Moore E (1922) Octomitus salmonis, a new species of intestinal parasite in trout. Trans Am Fish Soc 52:74-97

O'Brien GM, Ostland VE, Ferguson HW (1993) Spironucleusassociated necrotic enteritis in angelfish (Pterophyllum scalare). Can Vet J 34:301-303

Poppe TT, Mo TA, Iversen L (1992) Disseminated hexamitosis in sea-caged Atlantic salmon Salmo salar. Dis Aquat Org 14:91-97

Poynton SL, Morrison CM (1990) Morphology of diplomonad flagellates: Spironucleus torosa n. sp. from Atlantic cod Gadus morhua L., and haddock Melanogrammus aeglefinus (L.) and Hexamita salmonis Moore from brook trout Salvelinus fontinalis (Mitchill). J Protozool 37:369-383

Poynton SL, Fraser W, Francis-Floyd R, Rutledge P, Reed P, Nerad TA (1995) Spironucleus vortens n. sp. from the freshwater angelfish Pterophyllum scalare: morphology and culture. J Eukaryot Microbiol 42:731-742 
Siddall ME, Hong H, Desser SS (1992) Phylogenetic analysis of the Diplomonadida (Wenyon, 1926) Brugerolle, 1975: evidence for heterochrony in protozoa and against Giardia lamblia as a 'missing link' J Protozool 39:361-367

Specht D, Franscis-Floyd R, Bolon B, Watson C (1989) Significance of intestinal parasitism in the mortality of domestically-bred and imported angelfish. Pterophyllum scalare. Proc Int Assoc Aquat Anim Med 20:57-62

Sterud E (1998a) Electron microscopical identification of the flagellate Spironucleus torosa (Hexamitidae) from burbot Lota lota (Gadidae) with comments upon its probable introduction to this freshwater host. J Parasitol 84:947-953

Sterud E (1998b) In vitro cultivation and temperature-depen-

Editorial responsibility: Wolfgang Körting

Hannover, Germany dent growth of 2 strains of Spironucleus barkhanus (Diplomonadida: Hexamitidae) from Atlantic salmon Salmo salar and grayling Thymallus thymallus. Dis Aquat Org 33: $57-61$

Sterud E, Mo TA, Poppe TT (1997) Ultrastructure of Spironucleus barkhanus $\mathrm{n}$. sp. (Diplomonadida: Hexamitidae) from grayling Thymallus thymallus (L.) (Salmonidae) and Atlantic salmon Salmo salar L. (Salmonidae). J Eukaryot Microbiol 44:399-407

Tojo JL, Santamarina MT (1998) Oral pharmacological treatments for parasitic diseases of rainbow trout Oncorhynchus mykiss. I: Hexamita salmonis. Dis Aquat Org 33: $51-56$

Submitted: July 14, 1999; Accepted: November 19, 1999

Proofs received from author(s): January 5, 2000 